\title{
The Added Effects of Rice Husk Ash Against to Growth and Yield on Basil (Ocimum basilicum)
}

Dimas Panji Oktaviant ${ }^{1 *}$ ), Endang Dwi Purbajanti ${ }^{2}$ ), dan Susilo Budiyanto ${ }^{3}$ )

Agroecotechnology, Faculty of Animal and Agricultural Sciences, Diponegoro University, Tembalang Campus, Semarang 50275 - Indonesia

*) Corresponding E-mail: dmsoktav@gmail.com

\section{ABSTRACT}

Basil is a spice plant that is widely used as a culinary additive, fragrance, attraction, and anti-bacterial because it produces essential oils, basil oil. This research aimed to identify the effect of adding rice husk ash on different basil's cultivars on growth and yield of basil (Ocimum basilicum). This research used $4 \times 2$ factorial experiment pattern with Completely Randomized Design consisting of 5 replication. The first treatment was various type of basil's cultivars such as Genovese cultivars (K1) and Dark Opal cultivars (K2). The second treatment was doses of rice husk ash such as control or without giving rice husk ash (M0), $30 \mathrm{~g} /$ pot (M1), $35 \mathrm{~g} /$ pot (M2), and $40 \mathrm{~g} /$ pot (M3). The observed parameters were soil bulk density and porosity, plant height, leaves total, roots length, and leaves simplisia. The results showed that the application of husk ash can affect the increase in physical properties of the soil, but has not directly affected the growth parameters and yield of leaf simplisia. Dark Opal cultivars on all growth parameters showed higher yields, but Genovese cultivars showed higher yields or simplisia.

Keywords : Basil, Cultivars, Rice Husk Ash

\section{PENDAHULUAN}

Selasih merupakan tanaman herba, biasa dikenal dengan tanaman basil atau sweet basil. Dapat tumbuh dengan baik di daerah tropis maupun subtropis. Umumnya selasih dapat tumbuh mencapai hampir 1 meter, dengan daun mencapai 2,5 inchi atau kurang lebih $6 \mathrm{~cm}$. Rata - rata akar tanaman selasih yang tumbuh di lahan, dapat tumbuh dari $12 \mathrm{~cm}$ hingga tidak lebih dari $45 \mathrm{~cm}$ (Ekren et al., 2012). Terdapat 50 - 60 spesies dari genus Ocimum, dengan jumlah varietas kurang lebih 150 varietas. Antar kultivar tanaman selasih memiliki banyak kemiripan. Morfologi tanaman selasih sulit untuk dibedakan kecuali aroma daun, namun kandungan minyak dan komposisi fitokimia cenderung banyak memiliki perbedaan (Wahyuni et al., 2005).

Selasih kultivar Genovese (Ocimum basilicum cv. Genovese) atau kultivar Green Sweet merupakan salah satu kultivar yang banyak dikembangkan dan dibudidayakan, serta dimanfaatkan. Daun berwarna hijau cerah, sedikit berkerut, dengan ukuran diameter hingga $7 \mathrm{~cm}$, memiliki bunga berulir berwarna putih Tingginya mencapai kurang lebih 1 meter, memiliki aroma yang kuat dan pedas seperti cengkeh namun ada sensasi segar seperti mint (Hutson, 2003). Tanaman selasih kultivar Green sweet atau kultivar Genovese salah satu kultivar yang mengasilkan produksi simplisia yang tinggi 
dibandingkan dengan kultivar yang lain, dapat menghasilkan bobot kering daun panen mencapai 8,25 gram/tanaman hingga 12,565 gram/tanaman (Aboutalebi dan Hosseinifarahi, 2013).

Selasih kultivar Dark Opal (Ocimum basilicum cv. Dark Opal) dikenal karena berwarna ungu. Dikembangkan dari tanaman selasih ungu liar yang berada di alam, memiliki bentuk yang lebih ramping, sehingga memiliki kemampuan adaptasi yang tinggi terhadap lingkungan. Kultivar dark opal biasanya tumbuh mencapai tinggi 1 kaki atau kurang lebih $60 \mathrm{~cm}$, lebar daun kurang lebih $4 \mathrm{~cm}$. Daunnya semakin gelap di posisi paling atas atau dekat bunga, dan semakin ke bawah semakin pudar serta mulai muncul warna kehijauan (Gardner, 2014) Basil dengan varietas berwarna ungu mampu menghasilkan berat kering daun tiap tanamannya mencapai 1,462 gram/tanaman hingga 3,607 gram/tanaman (Ekren et al., 2012)

Abu sekam padi berasal dari sekam, yang dibakar hingga menjadi abu. Abu sekam padi yang dibakar secara sempurna pada suhu yang tinggi, akan berwarna putih dan tidak mengandung lignoselulosa karena telah terbakar habis, sedangkan abu sekam padi berwarna hitam masih mengandung lignoselulosa karena mengalami pembakaran yang kurang sempurna (Hutagalung dan Maulida, 2014). Lignoselulosa terdiri dari tiga polimer yaitu selulosa, hemiselulosa, dan lignin. Lignoselulosa sulit dimanfaatkan oleh mikroba penyubur tanah dikarenakan memiliki kandungan lignin, yang sulit didegradasi dan memiliki struktur yang komplek dan heterogen. Perlu adanya pengolahan terlebih dahulu untuk mendegradasi lignoselulosa sehingga dapat dimanfaatkan oleh mikroba penyubur tanah untuk mendukung kesuburan dan ketersediaan unsur hara di tanah, serta pertumbuhan tanaman (Anindyawati, 2010).

Abu sekam padi memiliki pengaruh yang besar terhadap porositas tanah. Abu sekam merupakan bahan organik yang bersifat porous, sangat ringan dan memiliki pori - pori yang halus, dengan luas permukaan bagian dalam mencapai $200-400 \mathrm{~nm}^{2}$, memiliki daya serap sekaligus daya saring yang tinggi, selain itu juga memiliki kandungan $\mathrm{K}$ yang tinggi (Tamtomo et al., 2015). Abu sekam padi sendiri memiliki banyak dimanfaatkan dengan tujuan untuk memperbaiki sifat tanah. Abu sekam padi memiliki kemampuan dalam menggemburkan tanah dan memperbaiki pori dalam tanah sehingga sangat menguntungkan bagi akar dalam menyerap unsur hara di dalamnya (Pane et al., 2014). Limbah abu sekam padi juga memiliki kandungan silika cukup tinggi 87 - $97 \%$, namun unsur hara $\mathrm{N}$ hanya 1\% (Kiswondo, 2011). Penggunaan dosis abu sekam yang kurang sesuai, dosis yang terlalu rendah, menunjukkan hasil dan pengaruh yang kurang baik terutama dalam meningkatkan nilai $\mathrm{pH}$ tanah hingga ke kondisi yang optimal, dan juga dalam peningkatan unsur hara makro seperti $\mathrm{P}, \mathrm{K}, \mathrm{Ca}$, dan Mg ke dalam tanah (Seipin et al., 2016).

Porositas tanah dalam budidaya tanaman dipengaruhi oleh beberapa faktor, salah satunya bahan organik. Bahan organik memiliki nilai $\mathrm{pH}$ yang bermacam - macam mulai dari 3 hingga 11 , 
bahan organik yang diolah dapat berikisar antara 5,5 hingga 8 , pada $\mathrm{pH}$ agak rendah dapat menyebabkan fungi berkembang dengan baik, pada $\mathrm{pH}$ agak tinggi atau alkalin, dapat menyebabkan kehilangan unsur nitrogen. Tanah yang memiliki persentase kandungan bahan organik yang rendah, akan berdampak pada meningkatnya nilai berat volume tanah, sehingga menyebabkan penurunan aerasi maupun porositas tanah (Sutanto, 2002). Berat volume tanah dengan kandungan bahan organik tinggi, cenderung akan memiliki nilai berat volume yang relative lebih rendah. Hal tersebut berpengaruh dengan ruang pori total yang tinggi (Kurnia et al., 2006). Tanah dengan persentase butiran pasir yang tinggi, atau banyak teksturnya banyak didominasi oleh pasir, memiliki luas permukaan yang kecil, pori - pori besar, aerasi tinggi, namun memiliki kemampuan menyimpan air yang rendah dan berperan kecil terhadap ketersediaan unsur hara atau sifat kimia dalam tanah (Rahmi dan Biantary, 2014).

Pertumbuhan dan produksi banyak dipengaruhi faktor eksternal dan faktor internal. Lingkungan tumbuh sebagai faktor eksternal berpengaruh terhadap pertumbuhan salah satunya pertumbuhan akar. Pertumbuhan akar salah satunya dipengaruhi oleh kondisi pori tanah. Akar akan tumbuh dengan baik ke dalam tanah dengan cara masuk kedalam tanah melalui pori makro tanah yang berukuran sama atau lebih besar daripada diameter akar atau dengan merubah lingkungan di sekitarnya (Hasanah, 2009). Kandungan unsur hara juga memiliki pengaruh terhadap pertumbuhan dan produksi tanaman. Kandungan unsur hara yang tersedia di tanah, salah satunya hara $\mathrm{N}$ yang tersedia bagi pertumbuhan tanaman, akan dapat diasimilasi oleh tanaman secara optimal, ditandai dengan pertumbuhan dan hasil produksi biomassa yang tinggi (Daza-Torres et al., 2017).

Faktor internal yang mempengaruhi pertumbuhan dan produksi tanaman diantaranya karena faktor genetik. Perbedaan karakteristik dua kultivar atau varietas yang berbeda, dapat terjadi karena terdapat perbedaan respon fisiologis tanaman yang disebabkan oleh genetik, tiap - tiap varietas tanaman terdiri atas genotipe yang berbeda, dan tiap genotipe menunjukkan respon berbeda terkait adaptifitas tanaman terhadap lingkungan tumbuh di sekitarnya (Fitrianah et al., 2012). Respon pertumbuhan dan produksi tanaman juga berkaitan dengan sifat morfologis tanaman. Tanaman dengan luas daun semakin besar, maka akan semakin banyak fotosintat atau asimilat yang dihasilkan oleh tanaman, dapat dialokasikan ke seluruh tanaman dan juga dapat disimpan untuk proses respirasi dan fotosintesis di daun (Fariudin et al., 2013)

Tujuan dari penelitian adalah mengkaji pengaruh penambahan abu sekam padi yang terbaik dan pengaruh jenis kultivar selasih serta interaksi antara penambahan abu sekam padi dan kultivar selasih terhadap pertumbuhan dan hasil tanaman selasih (Ocimum basilicum).

\section{MATERI DAN METODE}

Penelitian telah dilaksanakan pada tanggal 10 Mei 2019 - 31 Juli 2019 di Greenhouse Laboraturium Fisiologi dan Pemuliaan Tanaman, Fakultas Peternakan dan Pertanian, Universitas 
Diponegoro, Semarang. Analisis dilakukan di Laboratorium Ekologi dan Produksi Tanaman Fakultas Peternakan dan Pertanian, Universitas Diponegoro, Semarang, Jawa Tengah.

Alat yang digunakan dalam penelitian adalah pot, pot berukuran diameter $40 \mathrm{~cm}$, cangkul, sekop, ember, bak persemaian, ring sample, peti kayu, aluminium foil, picnometer, timbangan, amplop, label, penggaris skala terkecil $0,01 \mathrm{~cm}$, timbangan analitik, oven, buku, dan alat tulis. Bahan yang digunakan dalam penelitian ini adalah benih tanaman selasih kultivar Genovese (Ocimum basilicum cv. Genovese), tanaman selasih kultivar Dark Opal (Ocimum basilicum cv. Dark Opal), abu sekam padi, pupuk kompos, dan tanah dengan tekstur liat berpasir. Penelitian ini menggunakan Rancangan Acak Lengkap (RAL) pola faktorial 2 x 4 dengan 5 ulangan. Faktor pertama adalah faktor kultivar selasih yang terdiri dari 2 jenis yaitu Kultivar Genovese $\left(\mathrm{K}_{1}\right)$, dan Kultivar Dark Opal $\left(\mathrm{K}_{2}\right)$. Faktor kedua adalah faktor dosis abu sekam padi yaitu tanpa pemberian abu sekam padi (kontrol $\left.=M_{0}\right)$, pemberian abu sekam padi 30 g/pot setara 18 ton/ha $\left(M_{1}\right)$, pemberian abu sekam padi $35 \mathrm{~g} /$ pot setara 21 ton/ha $\left(\mathrm{M}_{2}\right)$, dan pemberian abu sekam padi $40 \mathrm{~g} /$ pot setara 24 ton/ha $\left(\mathrm{M}_{3}\right)$. Kombinasi perlakuan sebanyak 8 dengan 5 ulangan, sehingga terdapat 40 unit percobaan.

Penelitian dilakukan melalui persiapan, pemberian perlakuan, pemeliharaan, pengamatan, dan pengolahan data. Persiapan penelitian dilakukan pada bulan April 2019 yang meliputi persiapan alat dan bahan dengan membeli di toko pertanian daerah Semarang dan sekitarnya. Benih tanaman selasih diperoleh secara online. Tahap pelaksanaan dimulai pada akhir bulan Mei dan diawali dengan pembuatan media tanam semai dengan campuran tanah, arang sekam, dan pupuk kompos atau kandang (1:1:1) yang dimasukkan ke dalam tray semai. Benih selasih disemai hingga kurang lebih 2 minggu. Abu sekam padi untuk perlakuan dipersiapkan sesuai dengan menimbang abu sekam padi sesuai dosis. Tanah dicampurkan terlebih dahulu dengan pupuk kompos sebagai pupuk dasar, dengan dosis yang sudah disesuaikan untuk tiap potnya, campuran tanah dan pupuk dasar ditimbang sebesar $5 \mathrm{~kg}$ untuk masing - masing pot, dan baru dimasukkan ke dalam pot. Kemudian ditambahkan abu sekam padi sesuai dosis perlakuan dan dicampurkan. Benih selasih yang telah disemai dan sudah dapat dipindah, dipindahkan ke media perlakuan. Dilakukan pemeliharaan tanaman dengan penyiraman setiap hari pada sore hari dan pengendalian gulma yang tumbuh di sekitar tanaman penelitian. Tahap pengamatan meliputi pengambilan data sesuai parameter penelitian yang dilakukan setelah tanaman mencapai umur 1 Minggu Setelah Tanam (MST), kemudian pengamatan produksi saat telah memasuki masa panen pada umur 5 Minggu Setelah Tanam (MST), 7 Minggu Setelah Tanam (MST), hingga 9 Minggu Setelah Tanam (MST).

Parameter yang diamati dalam penelitian yaitu tanah, pertumbuhan dan hasil tanaman selasih. Variabel-variabel (1) berat volume tanah, (2) porositas tanah, (3) tinggi tanaman, (4) jumlah 
daun, (5) panajng akar, dan (6) simplisia daun. Data diolah dengan analisis ragam untuk mengetahui pengaruh perlakuan dan apabila ada pengaruh nyata perlakuan, dilanjutkan dengan Uji Jarak Berganda Duncan (UJGD) pada taraf $5 \%$.

\section{HASIL DAN PEMBAHASAN}

\section{Berat Volume Tanah}

Hasil analisis ragam menunjukkan

bahwa perlakuan penambahan abu sekam padi

Tabel 1. Berat Volume Tanah pada Perlakuan Abu Sekam Padi dan Kultivar Selasih

\begin{tabular}{|c|c|c|c|c|c|}
\hline \multirow[b]{2}{*}{ Kultivar } & \multicolumn{4}{|c|}{ Abu Sekam Padi } & \multirow[t]{2}{*}{ Rataan } \\
\hline & $\begin{array}{c}M_{0} \\
(0 \mathrm{~g} / \mathrm{pot})\end{array}$ & $\begin{array}{c}\mathrm{M}_{1} \\
(30 \mathrm{~g} / \mathrm{pot})\end{array}$ & $\begin{array}{c}\mathrm{M}_{2} \\
(35 \mathrm{~g} / \mathrm{pot})\end{array}$ & $\begin{array}{c}M_{3} \\
\text { (40 g/pot) }\end{array}$ & \\
\hline & - & ----------- & $n^{-3}$ & --- & \\
\hline $\begin{array}{c}\text { K } \\
\text { (Kultivar Genovese) }\end{array}$ & 0,94 & 0,84 & 0,84 & 0,84 & 0,86 \\
\hline $\begin{array}{c}\mathrm{K}_{2} \\
\text { (Kultivar Dark Opal) }\end{array}$ & 0,92 & 0,85 & 0,85 & 0,84 & 0,87 \\
\hline Rataan *) & $0,93^{a}$ & $0,85^{b}$ & $0,85^{b}$ & $0,84^{b}$ & 0,87 \\
\hline
\end{tabular}

*) Superskrip berbeda pada baris yang sama menunjukkan perbedaan nyata $(P<0,05)$

Hasil UJGD memperlihatkan bahwa pemberian abu sekam padi dapat menurunkan berat volume media tanah. Berat volume media tanam yang tidak diberi tambahan abu sekam padi memiliki nilai yang paling tinggi dibandingkan dengan media tanam yang diberikan tambahan abu sekam padi pada seluruh dosis perlakuan (Tabel 1). Nilai berat volume yang kecil menunjukkan tingkat kepadatan tanah semakin berkurang atau penambahan abu sekam meningkatkan volume pori yang ada di tanah. Didukung oleh Kurnia et al (2006) yang menjelaskan bahwa apabila berat volume tanah menunjukkan angka yang tinggi menandakan bahwa volume pori tanah tersebut lebih sedikit. Adanya penambahan abu sekam berpengaruh terhadap nilai berat volume tanah, namun perlakuan kultivar selasih dan interaksi antara penambahan abu sekam padi dan kultivar selasih tidak berpengaruh terhadap berat volume tanah. Nilai berat volume tanah akibat perlakuan pemberian abu sekam dan kultivas selasih, serta berdasarkan uji jarak berganda Duncan $(p<0,05)$ terdapat pada Tabel 1. . 
berdampak pada meningkatnya nilai berat volume tanah, sehingga menyebabkan penurunan aerasi maupun porositas tanah. Abu sekam padi memiliki partikel yang halus. Apabila Jumlah partikel halus lebih banyak dibandingkan partikel besar, akan berdampak pada jumlah total pori yang menjadi lebih banyak dengan banyak pori mikro yang terdapat di tanah. Tamtomo et al. (2015) menambahkan bahwa abu sekam padi memiliki pori - pori yang halus dengan ukuran mencapai 200 - $400 \mathrm{~nm}^{2}$, sehingga bersifat porous, dan memiliki daya serap sekaligus daya saring yang tinggi.

Tabel 2. Porositas Media Tanam pada dua Kultivar Selasih yang diberi Abu Sekam Padi

\begin{tabular}{cccccc}
\hline \hline Kultivar & \multicolumn{4}{c}{ Abu Sekam Padi } & Rataan \\
\cline { 2 - 4 } & $\begin{array}{c}\mathrm{M}_{0} \\
(0 \mathrm{~g} / \mathrm{pot})\end{array}$ & $\begin{array}{c}\mathrm{M}_{1} \\
(30 \mathrm{~g} / \mathrm{pot})\end{array}$ & $\begin{array}{c}\mathrm{M}_{2} \\
(35 \mathrm{~g} / \mathrm{pot})\end{array}$ & $\begin{array}{c}\mathrm{M}_{3} \\
(40 \mathrm{~g} / \mathrm{pot})\end{array}$ & \\
\hline $\begin{array}{c}\mathrm{K}_{1} \\
\text { Kultivar Genovese) }\end{array}$ & 34,32 & 38,20 & 41,00 & 41,55 & 38,77 \\
$\mathrm{~K}_{2}$ & 33,77 & 41,72 & 40,34 & 40,98 & 39,20 \\
$\begin{array}{c}\text { (Kultivar Dark Opal) } \\
\text { Rataan*) }\end{array}$ & $34,59^{\mathrm{b}}$ & $39,96^{\mathrm{a}}$ & $40,67^{\mathrm{a}}$ & $41,26^{\mathrm{a}}$ & 39,98 \\
\hline
\end{tabular}

*) Superskrip berbeda pada baris yang sama menunjukkan perbedaan nyata $(P<0,05)$

Hasil UJGD menunjukkan bahwa pemberian abu sekam padi dapat meningkatkan porositas media tanam. Nilai porositas media tanam yang tidak diberi tambahan abu sekam padi (34,59\%) lebih rendah jika dibandingkan dengan media tanam yang diberi tambahan abu sekam padi 30 gram/pot (39,96\%), 35 gram/pot $(40,67 \%)$, dan 40 gram/pot $(41,26 \%)$ (Tabel 2). Abu sekam yang diberikan kedalam tanah dapat memberikan pengaruh pada sifat fisik tanah. Hal tersebut sesuai dengan pendapat Gustia (2013) yang menyatakan bahwa abu sekam dapat

\section{Porositas Tanah}

Hasil analisis ragam menunjukkan bahwa perlakuan penambahan abu sekam padi berpengaruh terhadap porositas tanah. Perlakuan kultivar selasih dan interaksi antara penambahan abu sekam padi dengan kultivar selasih tidak berpengaruh terhadap porositas tanah. Nilai porositas tanah pada penambahan abu sekam padi dankultivar selasih serta berdasarkan uji jarak berganda Duncan $(p<0,05)$ disajikan pada Tabel 2. 
halus, memiliki daya saring dan daya serap yang tinggi. Adanya pori halus atau partikel halus yang banyak, menyebabkan tanah memiliki total pori dengan pori mikro yang lebih banyak, sehingga memiliki porositas yang tinggi. Perlakuan penambahan abu sekam padi antara 30 gram/pot, $35 \mathrm{gram} /$ pot, dan $40 \mathrm{gram} /$ pot tidak menunjukkan perbedaan yang signifikan terhadap nilai porositas tanah. Hal tersebut dapat disebabkan karena perbedaan nilai dosis yang kecil antar perlakuan. Pendapat tersebut dapat didukung oleh pendapat Seipin et al. (2016) yang menyatakan bahwa dosis yang kurang sesuai Tabel 3. Tinggi Tanaman pada Dua Kultivar Selasih dengan Tambahan Dosis Abu Sekam Padi

\begin{tabular}{cccccc}
\hline \hline \multirow{2}{*}{ Kultivar } & \multicolumn{4}{c}{ Abu Sekam Padi } & Rataan \\
\cline { 2 - 4 } & $\begin{array}{c}\mathrm{M}_{0} \\
(0 \mathrm{~g} / \mathrm{pot})\end{array}$ & $\begin{array}{c}\mathrm{M}_{1} \\
(30 \mathrm{~g} / \mathrm{pot})\end{array}$ & $\begin{array}{c}\mathrm{M}_{2} \\
(35 \mathrm{~g} / \mathrm{pot})\end{array}$ & $\begin{array}{c}\mathrm{M}_{3} \\
(40 \mathrm{~g} / \mathrm{pot})\end{array}$ & 82,8 \\
\hline $\begin{array}{c}\mathrm{K}_{1} \\
\text { (Kultivar Genovese) }\end{array}$ & 81,2 & 79,5 & 81,7 & 88,9 & 80,1 \\
$\begin{array}{c}\text { K2 } \\
\text { (Kultivar Dark Opal) }\end{array}$ & 81,1 & 83,6 & 79,3 & 76,5 & \\
Rataan & 81,15 & 81,55 & 80,5 & 82,7 & \\
\hline
\end{tabular}

Tinggi tanaman selasih pada semua perlakuan menunjukkan hasil yang tidak berbeda (Tabel 3). Penambahan abu sekam padi dapat meningkatkan kerapatan, dan porositas, namun belum menyebabkan perubahan pada tinggi tanaman. Tinggi tanaman pada kultivar Dark Opal pada perlakuan pemberian abu sekam padi, menunjukan hasil yang cenderung mengalami penurunan. Penurunan tersebut dapat terjadi dikarenakan abu sekam padi yang digunakan masih memiliki kandungan lignoselulosa yang cukup tinggi. Lignoselulosa tersebut sulit memiliki pengaruh yang rendah terhadap tanah, baik dalam perbaikan sifat fisik tanah maupun peningkatan unsur hara tanaman.

\section{Tinggi Tanaman}

Hasil analisis ragam menunjukkan bahwa perlakuan penambahan abu sekam padi, kultivar, dan interaksi antara penambahan abu sekam padi dengan kultivar selasih tidak berpengaruh terhadap tinggi tanaman selasih. Tinggi tanaman selasih pada dua kultivar dan penambahan abu sekam padi berdasarkan hasil uji jarak berganda Duncan $(p<0,05)$ disajikan pada Tabel 3. 
lignoselulosa, sedangkan abu sekam padi yang terbakar secara sempurna hingga berwarna putih, tidak mengandung lignoselulosa.

Penambahan abu sekam padi juga tidak memberikan pengaruh yang nyata terhadap pertumbuhan dikarenakan tidak begitu berdampak pada penambahan kandungan unsur hara, terutama $\mathrm{N}$ dan juga karena pengaruh tekstur tanah yang digunakan. Kiswondo (2011) menjelaskan bahwa abu sekam padi memiliki kandungan unsur hara $\mathrm{N}$ yang rendah hanya sekitar $1 \%$, namun memiliki kandungan silika yang tinggi. Dikarenakan tanah yang digunakan bertekstur liat berpasir, dengan kandungan pasir yang cukup tinggi, adanya penambahan abu sekam mampu meningkatkan porositas, namun daya simpan airnya rendah. Rahmi dan Biantary (2014) menjelaskan bahwa tanah liat berpasir memiliki kandungan pasir yang tinggi, dengan pori besar, tetapi kemampuan menyimpan airnya rendah dan juga berperan kecil terhadap peristiwa pembentukan unsur hara tanah. Tinggi tanaman juga tidak terpengaruh oleh perlakuan abu sekam disebabkan penggunaan dosis yang kurang sesuai. Tambahan dosis abu sekam padi yang kurang sesuai, mampu mempengaruhi sifat fisik tanah, namun kurang berdampak pada sifat kimia tanah. Didukung oleh Seipin et al. (2016) yang menjelaskan bahwa dosis abu sekam yang kurang sesuai, menunjukkan hasil dan pengaruh yang kurang baik dalam peningkatan nilai $\mathrm{pH}$ tanah hingga ke kondisi yang optimal, dan juga dalam peningkatan unsur hara makro. Dikarenakan penambahan abu sekam padi tidak berpengaruh terhadap penambahan unsur $\mathrm{N}$ dalam tanah, penambahan abu sekam padi tidak begitu berpengaruh terhadap pertumbuhan tanaman selasih.

Hasil penelitian (Tabel 3) memperlihatkan tinggi tanaman antar kultivar Genovese dan Dark Opal menunjukkan hasil yang tidak nyata, dikarenakan secara genetik memiliki hubungan kekerabatan yang dekat, sehingga cenderung memiliki kemiripan. Hutson (2003) menjelaskan bahwa tanaman selasih kultivar Genovese memiliki ukuran tinggi mencapai kurang lebih I meter, dan mampu tumbuh pada suhu yang cenderung hangat. Wahyuni et al. (2005) juga menjelaskan bahwa morfologi tanaman selasih banyak memiliki kemiripan, namun kandungan fitokimia cenderung banyak memiliki perbedaan. Gardner (2014) menambahkan bahwa selasih kultivar Dark Opal dapat tumbuh mencapai lebih dari $60 \mathrm{~cm}$ dan dapat tumbuh dengan baik pada suhu yang hangat. Respon pertumbuhan tinggi tanaman selasih dengan kultivar yang berbeda, cenderung akan memiliki kemiripan pada kondisi lingkungan yang sama.

\section{Jumlah Daun}

Hasil analisis ragam menunjukkan bahwa perlakuan penambahan abu sekam padi dan kultivar berpengaruh terhadap jumlah daun tanaman selasih, namun tidak terdapat pengaruh interaksi antara penambahan abu sekam padi dengan kultivar selasih terhadap jumlah daun. . Jumlah daun pada dua kultivar berbeda dan penambahan abu sekam padi berdasarkan hasil uji jarak berganda Duncan $(p<0,05)$ disajikan pada Tabel 4. 
Tabel 4. Jumlah Daun pada Dua Kultivar Selasih dengan Penambahan Abu Sekam Padi

\begin{tabular}{cccccc}
\hline \hline \multirow{2}{*}{ Kultivar } & \multicolumn{4}{c}{ Abu Sekam Padi } & Rataan * $)$ \\
\cline { 2 - 4 } & $\begin{array}{c}\mathrm{M}_{0} \\
(0 \mathrm{~g} / \mathrm{pot})\end{array}$ & $\begin{array}{c}\mathrm{M}_{1} \\
(30 \mathrm{~g} / \mathrm{pot})\end{array}$ & $\begin{array}{c}\mathrm{M}_{2} \\
(35 \mathrm{~g} / \mathrm{pot})\end{array}$ & $\begin{array}{c}\mathrm{M}_{3} \\
(40 \mathrm{~g} / \mathrm{pot})\end{array}$ & \\
\hline $\begin{array}{c}\text { K} \\
\text { Kultivar Genovese })\end{array}$ & 570 & 602 & 468 & 459 & $524,45^{\mathrm{b}}$ \\
$\begin{array}{c}\text { K2 } \\
\text { (Kultivar Dark Opal) } \\
\text { Rataan *) }\end{array}$ & 837 & 839 & 663 & 708 & $762,05^{\mathrm{a}}$ \\
\hline
\end{tabular}

*) Superskrip berbeda pada kolom dan baris yang sama menunjukkan perbedaan nyata $(P<0,05)$

Jumlah daun pada perlakuan pemberian

dosis abu sekam padi dan perlakuan kultivar selasih menunjukkan perbedaan antar perlakuan. Jumlah daun pada perlakuan abu sekam dosis 30 gram/pot lebih tinggi bila dibandingkan dengan kontrol, perlakuan dosis $35 \mathrm{gram} /$ pot dan 40 gram/pot. Jumlah daun pada perlakuan penambahan abu sekam padi dosis $35 \mathrm{gram} /$ pot lebih rendah dibandingkan dengan kontrol sedangkan perlakuan penambahan abu sekam $40 \mathrm{gram} /$ pot sama dengan kontrol (Tabel 4). Terjadinya kenaikan jumlah daun kemudian mengalami penurunan, dapat disebabkan karena penggunaan abu sekam padi yang belum terbakar secara sempurna. Penurunan tersebut dapat terjadi dikarenakan abu sekam padi yang ditambahkan ke dalam tanah memiliki kandungan lignoselulosa yang cukup tinggi. Lignoselulosa tersebut sulit atau tidak dapat dimanfaatkan oleh tanaman apabila belum terdegradasi oleh mikroba tanah. Didukung oleh pendapat Anindyawati (2010) yang menyatakan bahwa bahan tanaman yang mengandung lignoselulosa dapat dimanfaatkan menjadi pupuk organik, namun karena mengandung lignin dengan struktur yang kompleks dan sulit terdegradasi, perlu diproses terlebih dahulu, sehingga dapat dimanfaatkan untuk menyuburkan dan meningkatkan unsur hara yang ada di tanah. Ditambahkan oleh Hutagalung dan Maulida (2014) yang menjelaskan bahwa abu sekam padi yang terbakar secara sempurna, tidak memiliki kandungan lignoselulosa, namun abu sekam padi yang tidak terbakar secara sempurna, masih memiliki kandungan lignoselulosa.

Adanya penambahan abu sekam padi tetap dapat meningkatkan porositas dan pertumbuhan jumlah daun. Dikarenakan tanah yang digunakan adalah tanah liat berpasir, adanya penurunan jumlah daun setelahnya dikarenakan penambahan abu sekam yang kurang sesuai, porositasnya dapat lebih meningkat tetapi membuat air cepat menghilang, serta terjadi ketidak seimbangan $\mathrm{pH}$ yang ada di dalam tanah. Sutanto (2002) menjelaskan bahwa pada kondisi alkalin tinggi, akan menyebabkan hilangnya unsur hara Nitrogen. Rahmi dan Biantary (2014) juga menjelaskan bahwa tanah dengan tekstur liat berpasir memiliki kandungan pasir yang tinggi dan juga memiliki pori yang besar, namun kemampuan menyimpan airnya rendah, sehingga mempengaruhi pertumbuhan dan peristiwa kimia di tanah. Didukung oleh 
Seipin et al. (2016) menjelaskan bahwa penggunaan dosis abu sekam yang kurang sesuai, dapat memberikan pengaruh yang kurang baik terutama dalam keseimbangan nilai $\mathrm{pH}$ tanah, dosis abu sekam yang lebih tinggi juga dapat memperkaya unsur $\mathrm{Ca}$ dan Mg. Abu sekam padi bersifat alkali, sehingga menyebabkan tanah mengalami peningkatan $\mathrm{pH}$. Sehingga unsur hara $\mathrm{N}$ yang banyak dibutuhkan untuk pertumbuhan vegetatif salah satunya jumlah daun, menjadi berkurang atau kurang maksimal.

Hasil penelitian (Tabel 4) memperlihatkan perbedaan kultivar juga berpengaruh terhadap daun yang dihasilkan oleh tanaman. Kultivar Dark Opal menghasilkan jumlah daun yang lebih banyak dibandingkan dengan Kultivar Genovese. Adanya perbedaan daun tersebut salah satunya dipengaruhi oleh perbedaan kemampuan beradaptasi tanaman tersebut atau perbedaan respon fisologis tanaman yang disebabkan oleh faktor genetik. Fitrianah et al. (2012) menjelaskan bahwa perbedaan jumlah daun pada dua kultivar atau varietas yang berbeda, dikarenakan ada perbedaan respon fisiologis tanaman yang disebabkan oleh genetik, dimana tiap varietas tanaman terdiri atas sejumlah genotipe yang berbeda, dan tiap genotipe menunjukkan respon yang berbeda terkait penyesuaian tanaman terhadap lingkungan tumbuhnya. Gardner (2014) juga menjelaskan bahwa tanaman selasih kultivar Dark Opal pada awalnya dikembangkan berasal dari tanaman selasih ungu liar yang berada di alam, memiliki bentuk yang lebih ramping, sehingga memiliki kemampuan adaptasi yang tinggi terhadap lingkungan.

\section{Panjang Akar}

Hasil analisis ragam menunjukkan bahwa perlakuan penambahan abu sekam padi, kultivar yang berbeda, dan interaksi antara penambahan abu sekam padi dengan kultivar selasih yang berbeda, tidak memberikan pengaruh yang nyata terhadap panjang akar. Panjang akar tanaman selasih pada dua kultivar berbeda dan berbagai penambahan abu sekam padi berdasarkan hasil uji jarak berganda Duncan $(p<0,05)$ disajikan pada Tabel 5.

Tabel 5. Panjang Akar pada Dua Kultivar Selasih dengan Penambahan Abu Sekam Padi

\begin{tabular}{cccccc}
\hline \multirow{2}{*}{ Kultivar } & \multicolumn{4}{c}{ Abu Sekam Padi } & Rataan \\
\cline { 2 - 4 } & $\begin{array}{c}\mathrm{M}_{0} \\
(0 \mathrm{~g} / \mathrm{pot})\end{array}$ & $\begin{array}{c}\mathrm{M}_{1} \\
(30 \mathrm{~g} / \mathrm{pot})\end{array}$ & $\begin{array}{c}\mathrm{M}_{2} \\
(35 \mathrm{~g} / \mathrm{pot})\end{array}$ & $\begin{array}{c}\mathrm{M}_{3} \\
(40 \mathrm{~g} / \mathrm{pot})\end{array}$ & 5,3 \\
$\begin{array}{c}\mathrm{K}_{1} \\
\text { (Kultivar Genovese })\end{array}$ & 5,5 & 5,1 & 5,4 & 5,1 & 5,1 \\
$\begin{array}{c}\text { K2 } \\
\text { (Kultivar Dark Opal) } \\
\text { Rataan }\end{array}$ & 4,8 & 5,4 & 5,2 & 5,1 & \\
\hline
\end{tabular}

Penambahan abu sekam padi pada seluruh perlakuan, tidak memberikan pengaruh terhadap panjang akar (Tabel 5). Adanya penambahan abu sekam padi memang mempengaruhi perubahan iklim mikro tanah, salah satunya porositas, namun tidak 
mempengaruhi pertumbuhan akar. Tekstur dari tanah yang digunakan termasuk tanah liat berpasir dan tanah dengan kandungan pasir tinggi, memiliki aerasi yang tinggi dengan banyak pori makro, sehingga sudah banyak terdapat ruang bagi pertumbuhan akar. Hasanah (2009) menjelaskan bahwa akar akan tumbuh dengan baik ke dalam tanah, dengan masuk kedalam tanah melalui pori makro tanah yang berukuran sama atau lebih besar daripada diameter akar atau dengan merubah lingkungan di sekitarnya. Adanya peningkatan porositas tanah, sesuai dengan Pane et al. (2014) dijelaskan bahwa abu sekam padi memiliki kemampuan dalam memperbaiki pori dan menggemburkan tanah, sehingga menguntungkan bagi pertumbuhan akar. Perlakuan abu sekam padi tidak berpengaruh pada pertumbuhan akar dikarenakan kondisi tanah sudah cukup optimum bagi pertumbuhan akar.

Hasil penelitian (Tabel 5) memperlihatkan perbedaan kultivar selasih, yaitu kultivar Genovese dan kultivar Dark Opal tidak mempengaruhi performa dari pertumbuhan akar. Hal tersebut dapat disebabkan karena kedua kultivar tersebut masih memiliki kedekatan

Tabel 6. Simplisia Daun/Bobot Kering Daun Panen pada Dua Kultivar Selasih dengan Penambahan Abu Sekam Padi

\begin{tabular}{cccccc}
\hline \multirow{2}{*}{ Kultivar } & \multicolumn{4}{c}{ Abu Sekam Padi } & \multirow{2}{*}{ Rataan * $)$} \\
\cline { 2 - 4 } & $\begin{array}{c}\mathrm{M}_{0} \\
(0 \mathrm{~g} / \mathrm{pot})\end{array}$ & $\begin{array}{c}\mathrm{M}_{1} \\
(30 \mathrm{~g} / \mathrm{pot})\end{array}$ & $\begin{array}{c}\mathrm{M}_{2} \\
(35 \mathrm{~g} / \mathrm{pot})\end{array}$ & $\begin{array}{c}\mathrm{M}_{3} \\
(40 \mathrm{~g} / \mathrm{pot})\end{array}$ & \\
\hline $\mathrm{K}_{1}$ & 4,33 & 4,35 & 4,46 & 4,95 & $4,53^{\mathrm{a}}$ \\
$\begin{array}{c}\text { (Kultivar Genovese) } \\
\mathrm{K}_{2}\end{array}$ & 3,176 & 3,81 & 3,81 & 3,31 & $3,53^{\mathrm{b}}$ \\
$\begin{array}{c}\text { (Kultivar Dark Opal) } \\
\text { Rataan }\end{array}$ & 3,752 & 4,08 & 4,13 & 4,13 & \\
\hline
\end{tabular}

*) Superskrip berbeda pada kolom yang sama menunjukkan perbedaan nyata $(P<0,05)$

secara genetik dan kemungkinan memiliki adaptasi yang tidak jauh berbeda terkait iklim mikro tanah. Wahyuni et al. (2005) menjelaskan bahwa morfologi tanaman selasih banyak memiliki kemiripan, sulit untuk dibedakan kecuali karakter aroma daun. Tanaman selasih yang tumbuh di dalam pot juga memiliki keterbatasan dalam proses pertumbuhannya, sehingga akar tidak dapat tumbuh hingga ke kondisi optimum. Didukung oleh Ekren et al. (2012) yang menyatakan bahwa rata - rata akar tanaman selasih yang tumbuh di lahan, dapat tumbuh dari $12 \mathrm{~cm}$ hingga tidak lebih dari $45 \mathrm{~cm}$.

\section{Simplisia Daun}

Hasil analisis ragam menunjukkan bahwa perlakuan jenis kultivar selasih berpengaruh nyata terhadap simplisia daun panen, tetapi perlakuan penambahan abu sekam padi dan interaksi antara penambahan abu sekam padi dengan kultivar selasih tidak berpengaruh terhadap bobot simplisia/bobot kering daun panen. Simplisia daun/bobot kering panen pada dua kultivar berbeda dan berbagai penambahan abu sekam padi berdasarkan hasil uji jarak berganda Duncan $(p<0,05)$ disajikan pada Tabel 6. 
Penambahan abu sekam padi tidak memperlihatkan perbedaan terhadap parameter simplisia/bobot kering daun panen (Tabel 6). Perlakuan penambahan abu sekam padi hanya mampu memperbaiki porositas tanah, tetapi belum mampu mempengaruhi simplisia/bobot kering daun panen. Hal tersebut dapat disebabkan karena dosis yang kurang sesuai dan tekstur tanah yang banyak mengandung pasir dengan pori - pori makro yang banyak. Sesuai dengan Rahmi dan Biantary (2014) yang menjelaskan bahwa tanah dengan kandungan pasir tinggi memiliki kemampuan menyimpan air yang rendah sehingga mempengaruhi ketersediaan unsur hara di tanah. Seipin et al. (2016) menambahkan bahwa perlakuan dosis pemberian abu sekam yang kurang tepat, mempengaruhi nilai $\mathrm{pH}$ tanah dan juga dalam peningkatan unsur hara makro seperti $\mathrm{P}, \mathrm{K}, \mathrm{Ca}$, dan Mg ke dalam tanah. Tanah juga akan dengan mudah mengalami kehilangan air hingga pencucian, sehingga kandungan unsur hara $\mathrm{N}$ cepat hilang, tidak dapat diserap secara maksimal atau optimum oleh tanaman. Hal tersebut sesuai dengan pendapat Daza-Torres et al. (2017) bahwa kondisi tanah yang mudah mengalami pencucian, unsur hara $\mathrm{N}$ akan turut hilang dan tidak dapat diserap oleh tanaman, sehingga produksi biomassanya akan rendah.

Hasil penelitian (Tabel 6) memperlihatkan perbedaan kultivar berpengaruh nyata terhadap simplisia/bobot kering daun panen. Kultivar Genovesememiliki hasil panen bobot kering daun panen/simplisia yang secara nyata lebih tinggi dibandingkan dengan kultivar Dark Opal. Hal tersebut disebabkan karena kultivar Genovese (Green Sweet) memiliki hasil panen daun kering atau simplisia yang lebih tinggi jika dibandingkan dengan hasil panen daun kering atau simplisia dari kultivar Dark Opal. Hasil penelitian dari Ekren et al. (2012) menunjukkan bahwa basil dengan varietas berwarna ungu mampu menghasilkan berat kering daun tiap tanamannya mencapai 1,462 gram/tanaman hingga 3,607 gram/tanaman. Berdasarkan hasil penelitian dari Aboutalebi dan Hosseinifarahi (2013) memperoleh hasil bahwa tanaman selasih dengan kultivar Green sweet, dapat menghasilkan berat kering daun panen mencapai 8,25 gram/tanaman hingga 12,565 gram/tanaman.

Kultivar Genovese mampu menghasilkan fotosintat yang lebih tinggi dibandingkan dengan kultivar Dark Opal. Secara morfologis, kultivar Genovese memiliki ukuran daun yang lebih lebar dibandingkan kultivar Dark Opal. Hal tersebut dijelaskan oleh Hutson (2003) yang menjelaskan bahwa selasih kultivar Genovese memiliki daun berwarna hijau cerah, sedikit berkerut, dan berukuran hingga $7 \mathrm{~cm}$, sedangkan kultivar Dark Opal, memiliki lebar daun kurang lebih $4 \mathrm{~cm}$, dan daunnya akan berwarna semakin gelap saat makin mendekati bunga. Pernyataan tersebut ditambahkan oleh Fariudin et al. (2013) yang menjelaskan bahwa semakin besar luas daun, maka akan semakin banyak fotosintat atau asimilat yang dihasilkan oleh tanaman, dapat dialokasikan ke seluruh tanaman dan juga dapat disimpan untuk proses respirasi dan fotosintesis di daun. 


\section{SIMPULAN}

Berdasarkan penelitian yang dilakukan penambahan abu sekam padi dapat mempengaruhi sifat fisik tanah yaitu menurunkan berat volume tanah, dan meningkatkan porositas, namun belum berpengaruh terhadap pertumbuhan dan hasil panen simplisia, kecuali parameter jumlah daun. Kultivar Dark Opal pada seluruh parameter pertumbuhan, menghasilkan nilai yang lebih tinggi dibandingkan dengan kultivar Genovese, namun kultivar Genovese menunjukkan hasil panen atau simplisia yang lebih tinggi dibandingkan dengan kultivar Dark Opal.

\section{UCAPAN TERIMA KASIH}

Terima kasih kepada Prof. Dr. Ir. Endang Dwi Purbajanti, M.S. sebagai dosen pembimbing utama dan Dr. Ir. Susilo Budiyanto, M.Si. sebagai pembimbing anggota, dan Bapak Ahmad Baroha S.Pt selaku laboran yang telah membantu jalannya penelitian.

\section{DAFTAR PUSTAKA}

Aboutalebi, A., \& Hosseinifarani, M. (2013). Evaluation of growth and yield of originicaly-grown basil (Ocimum basilicum) in soilless culture. Journal of Food Agricultural and Environment, 11(1) , 299301.

Anindyawati, T. (2010). Potensi selulase dalam mendegradasi lignoselulosa limbah pertanian untuk pupuk organik. Berita Selulosa, 45(2), 70-77.

Daza-Torres, M. C., Arias-Prado, P. C., ReyesTrujillo, A., \& Urrutia-Cobo, N. (2017). Basil (Ocimum basilicum L.) water needs calculated from the crop coefficient.
Journal Ingenieria e Investigacion, 37(3), 8-16.

Ekren, S., Sonmez, C., Ozcakal, E., Kurttas, E., Bayram, Y. S. K., \& Gurgulu, H. (2012). The effect of different irrigation water levels in yield and quality characteristics of purple basil (Ocimum basilicum L.). Agricultural Water Management, 109, 155-161.

Fariudin, R., Sulistyaningsih, E., \& Waluyo. E. (2013). Pertumbuhan dan hasil dua kultivar selada (Lactuca sativa L.) dalam akuaponika pada kolam gurami dan kolam nila. Jurnal Vegetalika, 2(1), 1-16.

Fitrianah, L., Fatimah, S., \& Hidayati, Y. (2012). Pengaruh komposisi media tanam terhadap pertumbuhan dan kandungan saponin pada dua varietas tanaman gondola (Basella sp.). Jurnal Agrovigor, 5(1),34-47.

Gardner, J. A. (2014). Living with herbs. Vermont, US: The Countryman Press.

Hasanah, U. (2009). Respon tanaman tomat (Lycopersicum esculentum Mill) pada awal pertumbuhan terhadap keragaman ukuran agregat entisol. Jurnal Agroland, 16(2), 103-109.

Hutagalung, C. O. dan Maulida. (2014). Karakteristik fourier transform infra red dan kekuatan bentur komposit poliester tak jenuh berpengisi abu sekam padi putih. Jurnal Teknik Kimia USU, 3(1), 23-26.

Hutson, L. (2003). The herb garden cookbook. Austin, US: University of Texas Press.

Kiswondo, S. (2011). Penggunaan abu sekam dan pupuk ZA terhadap pertumbuhan dan hasil tanaman tomat (Lycopersicum esculentum Mill.). Jurnal Embryo, 8(1), 917. 
Kurnia, U., Agus, F., Adimihardja, A., dan Dariah, A. (2006). Sifat fisik tanah dan metode analisisnya. Badan Penelitian dan Pengembangan Pertanian, Departemen Pertanian.

Pane, M. A., Damanik, M. M. B., dan Sitorus, B. (2014). Pemberian bahan organik kompos jerami padi dan abu sekam padi dalam memperbaiki sifat kimia tanah ultisol serta pertumbuhan tanaman jagung. e-J. Agroekoteknologi, 2(4), 1426-1432.

Rahmi, A. dan Biantary, M. P. (2014). Karakteristik sifat kimia tanah dan status kesuburan tanah lahan pekarangan dan lahan usaha tani beberapa kampung di Kabupaten Kutai Barat. J. Ziraa.ah, 39(1), 30-36.
Seipin, M., Sjofjan, J., dan Ariani, E. (2016). Pertumbuhan dan produksi tanaman jagung manis (Zea mays saccharata Sturt) pada lahan gambut yang diberi abu sekam padi dan trichokompos jerami padi. JOM Faperta, 3(2), 1-15.

Sutanto, R. (2002). Penerapan Pertanian Organik. Yogyakarta, Indonesia: Kanisius.

Tamtomo, F., Rahayu, S., dan Suyanto, A. (2015). Pengaruh aplikasi kompos jerami dan abu sekam padi terhadap produksi dan kadar pati ubijalar. Jurnal Agrosains, 12(2), 1-7.

Wahyuni, S., Hadipoentyanti, E., dan Kardinan, A. (2005). Karakteristik morfologi dan kandungan minyak dua nomor selasih hutan (Ocimum gratissimum L.). Buletin Tanaman Rempah dan Obat. 16(1), 1017. 